\title{
IbM Transplantasi Terumbu Karang Kelompok Masyarakat Desa Kombang dan Masyarakat Dusun Gili Labak Sebagai Media Meningkatkan Potensi Wisata Selam
}

\author{
Mahfud Efendy ${ }^{1}$ dan Firman Farid Muhsoni ${ }^{1}$ \\ ${ }^{1}$ Fakultas Pertanian Universitas Trunojoyo Madura
}

\begin{abstract}
Abstrak
Pulau Gili labak memiliki luas terumbu karang mencapai 66 ha, dengan kondisi karang hidup seluas 48,7\% dan terumbu karang dalam kondisi mati seluas 51,3\%. Tujuan pengabdian memberikan pelatihan dan melakukan transplantasi terumbu karang atau budidaya karang untuk menjaga dan merehabilitasi kondisi terumbu karang, Metode kegiatan survei langsung kondisi karang (skin diving) dan pelatihan serta survei kondisi karang dengan metode foto bawah air. Masalah mitra yaitu tutupan karang keras yang hidup diatasi dengan rehabilitasi terumbu karang dengan transplantasi terumbu karang dan penyuluhan dan papan himbuan agar tidak membuang sampah sembarangan. Tahapan pengabdian: 1) Persiapan (pembuatan rak untuk tranplantasi karang, Pembuatan Poster, banner dan stiker, Pembuatan video yang di upload di media youtube; 2) penyuluhan dan pelatihan (materi Materi tentang manfaat terumbu, Materi tentang potensi wisata Pulau Gili Labak, Materi tentang teknik transplantasi terumbu karang) 3) evaluasi dan pendampingan; 4) pembuatan papan himbauan. Evaluasi Pelatihan sebelum pelatihan $92 \%$ peserta pelatihan tidak tahu manfaat pentingnya terumbu karang, dengan pelatihan $92 \%$ menjadi tahu manfaat pentingnya terumbu karang, dengan pelatihan $84 \%$ peserta menganggap perlu sekali terumbu karang dijaga, dengan pelatihan $88 \%$ peserta menjadi tahu sekali jika terumbu karang bisa di tanam/budidayakan, dengan pelatihan $88 \%$ berpendapat pelatihan ini bermanfaat sekali untuk memberikan pemahaman terhadap perlunya menjaga terumbu karang, $84 \%$ peserta pelatihan berpendapat pelatihan ini bermanfaat sekali untuk memberikan pemahaman cara menanam terumbu karang; $84 \%$ peserta pelatihan berpendapat sangat bersedia di kemudian hari menjaga terumbu karang.
\end{abstract}

Kata Kunci : Pulau Gili Labak, transplantasi terumbu karang, ekowisata

\section{PENDAHULUAN}

Kabupaten Sumenep dengan potensi terumbu karang, mangrove dan jumlah pulau terbesar di Jawa Timur merupakan kabupaten yang mempunyai sumberdaya alam sangat potensial untuk dimanfaatkan (Muhsoni et.al, 2011). Luas mangrove di Kabupaten Sumenep mencapai mencapai $12.558 \mathrm{Ha}$, dengan kondisi kerapatan tajuk lebat 1.719,3 Ha (14 \%), tajuk sedang $6.407,3 \mathrm{Ha} \mathrm{(51 \% )} \mathrm{dan} \mathrm{tajuk} \mathrm{jarang} \mathrm{4.432,3} \mathrm{Ha} \mathrm{(35}$ $\%)$. Sedangkan luas terumbu karang di Kabupaten Sumenep mencapai 73.911 ha (Muhsoni , 2015a). Jumlah pulau ada 106 pulau, dengan jumlah pulau yang berpenghuni mencapai 48 pulau dan 78 pulau tidak berpenghuni (Muhsoni, 2016). Disisi lain daerah ini juga mempunyai sumberdaya alam minyak bumi dan gas bumi yang sangat besar. Tetapi dalam pemanfaatannya terbukti belum optimal, dan dalam pemanfaatannya belum sepenuhnya untuk kesejahteraan masyarakat. Hal ini bisa dilihat dari masih banyak masyarakat Sumenep, terutama masyarakat kepulauan yang perekonomiannya masih rendah.

Salah satu pulau di Kabupaten Sumenep yang saat ini yang menjadi daya tarik wisata adalah Pulau Gili labak. Luas terumbu karang di Pulau Gili Labak mencapai 66 ha, dengan kondisi karang hidup seluas $48,7 \%$ dan terumbu karang dalam kondisi mati seluas 51,3\%. Jenis karang yang dominan adalah Stylophora (Branching ). dengan luas terumbu karang sebesar 29,27 (Muhsoni, 2015b). Kondisi pulau Gili Labak sangat potensial untuk pengembangan ekowisata selam, ekowisata snorkeling dan ekowisata pantai. Kondisi pulau ini hasil pengukuran lapang menunjukkan : Jenis 
ikan karang mencapai 20-75 jenis ikan karang, kecerahan perairan mencapai $100 \%$ disemua lokasi pengukuran, tutupan komunitas karang mencapai $41,9 \%$, jenis life-form yang ditemukan lebih besar dari 10 jenis, suhu perairan mencapai 30,9-31,2 0C , salinitas mencapai antara 30-32 $\% 0$, kedalam perairan di pulau Gili Labak ratarata 1-10 $\mathrm{m}$ dan kecepatan arus di pulau ini antara 5,8-15,2 cm/dt. Rute atau akses menuju Pulau Gili Labak melalui beberapa rute : (1)Pelabuhan Kalianget dari jantung kota Sumenep, (2) Desa Lobuk salah satu desayang terdapat dermaga atau pelabuhan mini, (3) Tanjung Saronggi dermaga yang banyak tersedia perahu kecil untuk menuju Gili Labak, (4) Desa Kombang di kecamatan Talango di Pulau Poteran.

Degradasi terumbu karang salah satunya akibat kegiatan manusia antara lain: penangkapan ikan dengan menggunakan bahan dan/atau alat yang dapat membahayakan sumber daya ikan dan lingkungannya; penambangan dan pengambilan karang; penangkapan yang berlebih; pencemaran perairan; kegiatan
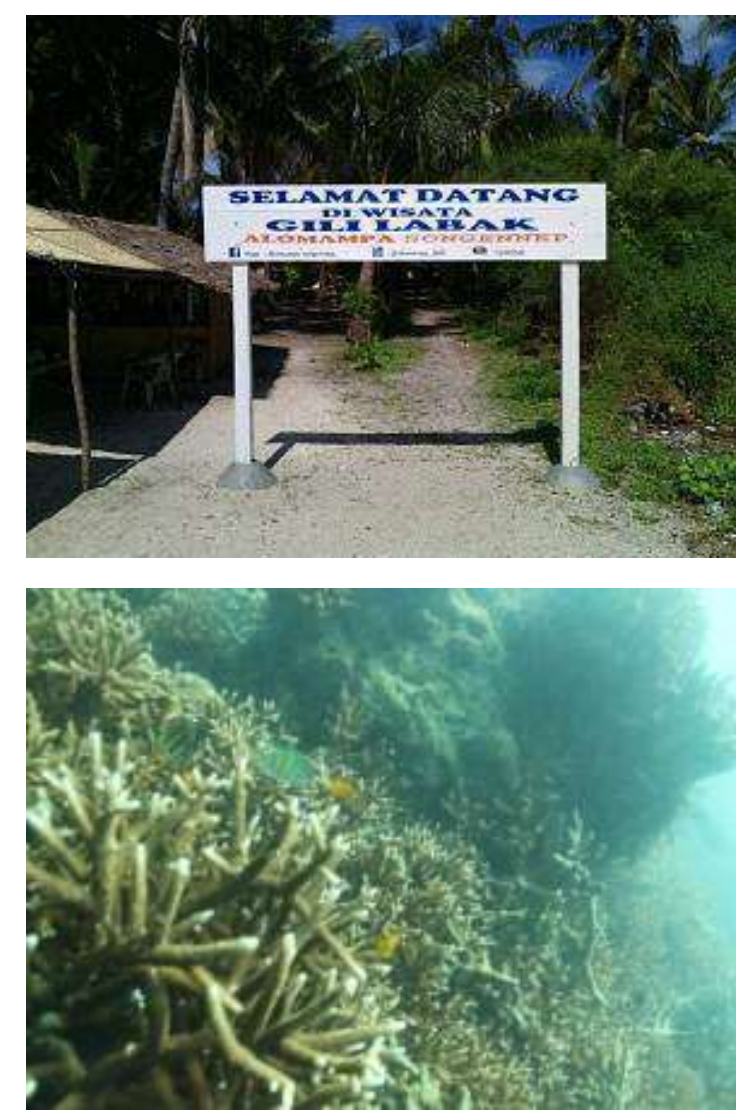

pembangunan di wilayah pesisir; kegiatan pembangunan di wilayah hulu (Kepmen No. KEP.38/MEN/2004). Semakin dikenalnya Pulau Gili Labak (masuk acara My Trip My Adventure) menjadikan pulau ini semakin dikenal dan banyak dikunjungi wisatawan. Berkembangnya wisata di Pulau Gili Labak akhir-akhir ini menimbulkan ancaman yang serius terhadap kondisi lingkungan, terutama terumbu karang di Pulau Gili Labak. Kesadaran masyarakat akan pentingnya terumbu karang dan perlunya merawat terumbu karang masih belum ada. Mereka hanya mengeksploitasi terumbu karang baik untuk wisata ataupun penangkapan ikan tanpa ada upaya melakukan rehabilitasi.

Tujuan dari pengabdian ini adalah memberikan pelatihan dan melakukan transplantasi terumbu karang atau budidaya karang untuk menjaga dan merehabilitasi kondisi terumbu karang di Pulau Gili Labak, bahkan dapat mempunyai nilai ekonomis bisa dijual hasil penanaman terumbu karang tersebut kepada para wisatawan. Selain itu program ini dapat memperbaiki kondisi terumbu karang
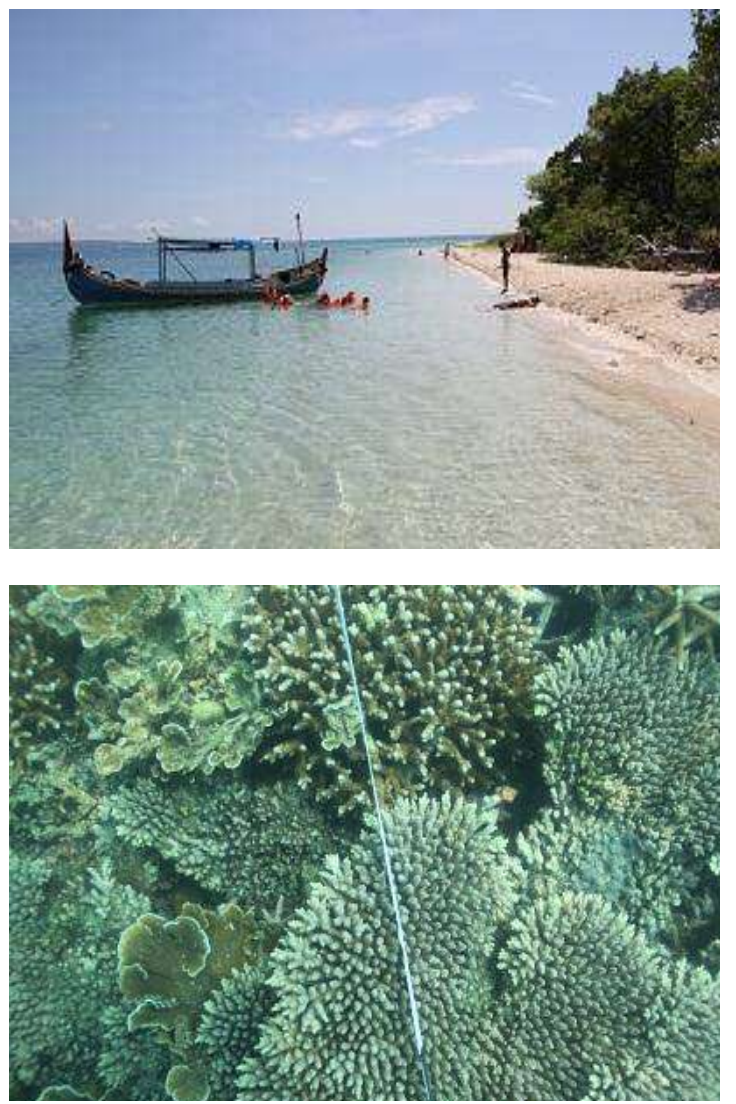

Gambar 1. Kondisi Pulau Gili Labak dan Terumbu Karang di Pulau Gili Labak 
akibat semakin berkembangnya wisata selam/snorkeling. Tetap terjaganya kondisi karang secara tidak langsung akan menciptakan kenyamanan dalam kehidupan bermasyarakat Gili Labak, karena wisata tetap bisa berkembang, kondisi ekosistem karang tetap terjaga dan perekonomian masyarakat meningkat. Melalui program ini diharapkan dapat meningkatkan keterampilan masyarakat dalam rehabilitasi karang melalui transplantasi karang. Kelompok masyarakat di Pulau Gili Labak adalah Kelompok masyarakat Desa Kombang dan Masyarakat Dusun Gili Labak. Karakteristik mitra masyarakat yang akan terlibat dalam pengabdian ini adalah :

1. Kelompok Masyarakat Desa Kombang, Kelompok masyarakat ini ada di Desa Kombang Pulau Poteran yang masih satu desa dengan dusun di Pulau Gili Labak. Mayoritas masyarakat di desa ini berprofesi sebagai nelayan yang melakukan penangkapan di Pulau Gili Labak. Sehingga perlu penyadaran agar aktivitas penangkapannya tidak merusak terumbu karang di Pulau Gili Labak.

2. Kelompok Masyarakat Dusun Gili Labak yang berada dan tinggal di Pulau Gili Labak. Gili Labak sendiri merupakan pulau kecil yang merupakan bagian dari Desa Kombang RW 3 RT 5, Pulau Poteran, Kecamatan Talango. Penduduk di Pulau Gili Labak terdapat 35 kepala keluarga (KK). Sedangkan jumlah penduduk yang menghuni Gililabak tidak lebih dari 100 orang. Tidak ada anak usia sekolah di pulau Gili Labak, karena anak-anak usia sekolah di Gili Labak sengaja diungsikan ke Pulau Poteran untuk

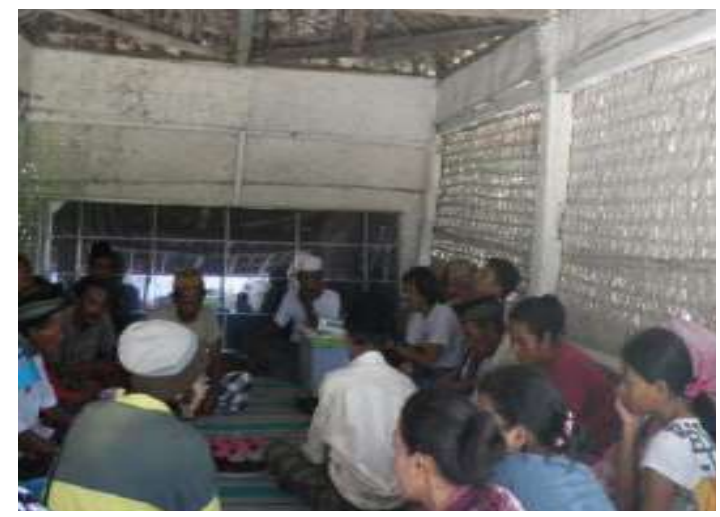

mendapatkan pendidikan karena di Gili Labak tidak ada sekolah. Kelompok masyarakat disisni yang berprofesi menjadi nelayan dan memanfaatkan wisata sebagai mata pencaharian dengan menyewakan snorkeling, pelampung atau kapal, seta membuka warung makanan.

Semakin dikenalnya Pulau Gili Labak sebagai destinasi wisata, maka peningkatan jumlah wisatawan meningkat. Peningkatan jumlah wisata ini menyebabkan beberapa hal, antara lain :

- Banyaknya terumbu karang yang rusak dikarenakan ulah wisatawan yang tidak ramah lingkungan dengan melakukan aktivitas diving atau snorkeling yang merusak dan membuang sampah sembarangan. Sampah- sampah ini terutama sampah plastik yang mencemari perairan dan wilayah terumbu karang yang menyebabkan menghambat pertumbuhan terumbu karang

- Masih adanya penangkapan ikan dan melakukan jangkar kapal di wilayah terumbu karang yang menyebabkan terumbu karang rusak. Hal ini disebabkan karena belum sadarnya masyarakat terhadap keberadaan terumbu karang yang yang besar bagi kehidupan manusia dan lingkungan. Sulistianto (2010); Subekti, Suradi, Imam T (2013) menjelaskan terumbu karang bukan sekedar menjadi tempat hidup dan berkembang biota laut belaka. Terumbu karang menyediakan tempat tinggal, mencari tmakan, dan berkembang biak bagi berbagai biota laut, sumber keanekaragaman hayati yang inggi, pelindung pantai dan pesisir, mengurangi pemanasan global.

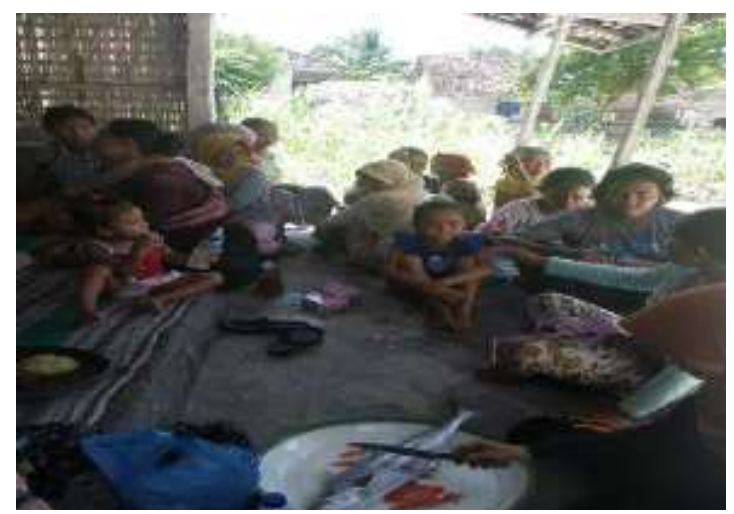

Gambar 2. Kelompok Masyarakat Dususn Gili Labak 
- Belum tahunya masyarakat tentang pengetahuan teknologi tentang rehabilitasi karang yang dapat memperbaiki kondisi terumbu karang, terutama transplantasi karang, terbatasnya pengetahuan tentang adopsi teknologi transplantasi karang sangat berkaitan dengan kurang intensifnya peran penyuluh (PP) dari dinas terkait. Dengan demikian tidak adanya pengetahuan tentang rehabilitasi terumbu karang baik teknik dan cara transplantasi karang baik dengan tipe piramida persegi 3, sistem rak dengan metode substrat semen (cor) dan pipa paralon. Teknologi transplantasikarang (coral transplantation) adalah usaha mengembalikan terumbu karang melalui pencangkokan atau pemotongan karang hidup untuk ditanam di tempat lain atau di tempat yang karangnya telah mengalami kerusakan. Bertujuan untuk pemulihan atau pembentukan terumbu karang alami. Terbatasnya pengetahuan tentang teknologi transplantasi dan pemilihan bibit karang merupakan komponen yang menyebabkan sulitnya terumbu karang diperbaiki.

Berdasarkan hasil wawancara dan pengamatan dilapang pada tanggal 6 Maret 2015 dengan kelompok masyarakat Gili Labak dan tanggal 28 April 2016, mendapatkan beberapa masalah yang dihadapi kelompok masyarakat pulau Gili Labak untuk memperbaiki kondisi terumbu karang yang ada, antara lain : 1) Rusaknya terumbu karang akibat aktivitas penangkapan dan wisata, 2) kerusakan lingkungan pesisir akibat pembuangan sampah, 3) masalah air tawar, 4) keberadaan listrik yang saat ini masih menggunakan diesel, 5)
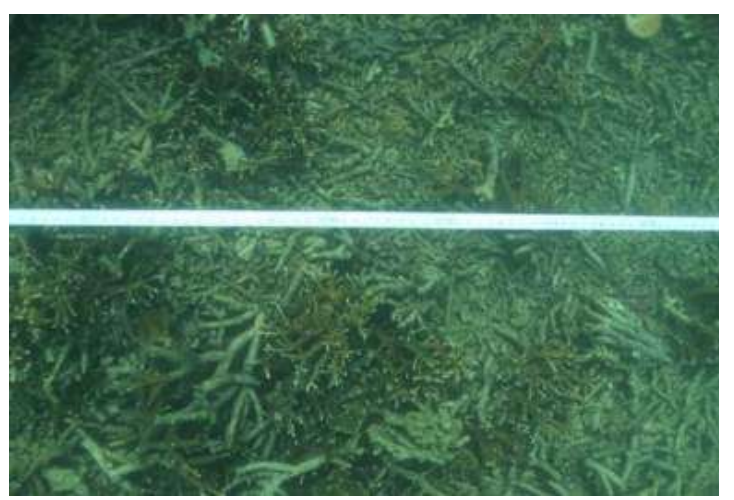

masyarakat belum memanfaatkan potensi wisata secara optimal untuk meningkatkan perekonomian. Disepakati prioritas masalah yang dilakukan dalam pengabdian ini adalah penanganan kerusakan terumbu karang. Penanganan kerusakan terumbu karang dibagi menjadi beberapa masalah :

1. Kerusakan terumbu karang akibat kegitan wisata, penangkapan ikan dan kegiatan melakukan jangkar kapal di wilayah terumbu karang, hal ini menyebabkan kerusakan pada terumbu karang. Oleh karena ini diperlukan kegiatan yang arahannya untuk menyadarkan masyarakat akan manfaat dan pentingnya terumbu karang.

2. Belum tahunya masyarakat tentang bagaimana melakukan rehabilitasi terumbu karang.

\section{METODE}

\section{- Metode Pendekatan}

Metode pendekatan yang dilakukan untuk menyelesaikan permasalahan mitradilakukan dengan pelatihan transfer iptek dan pendampingan. Pelatihan da pendampingan dilakukan kepada Kelompok Masyarakat Desa Kombang dan Masyarakat Dusun Gili Labak. Pelatihan dilakukan untuk mentransfer Iptek terkait dengan teknologi rehabilitasi terumbukarang dengan metode transplantasi terumbu karang.

\section{- Rencana Kegiatan}

Rencana kegiatan yang dilakukan untuk kegiatan IbM transplantasi terumbu karang di Pulau Gili Labak adalah :

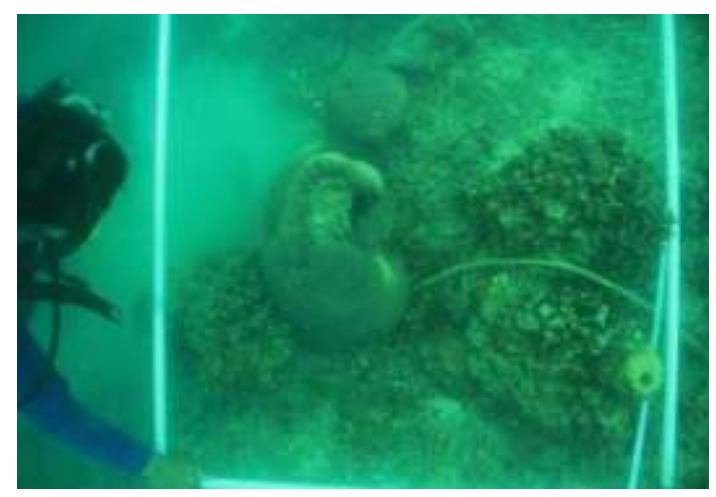

Gambar 3. Kerusakan Terumbu Karag di Pulau Gili Labak 
1. Survei lokasi kelompok masyarakat Desa Kombang dan masyarakat Dusun Gili Labak. Pada kegiatan ini dilakukan identifikasi potensi dan permasalahan lebih mendalam melalui survei langsung kondisi karang (skin dive) dan wawancara bersama kelompok nelayan, pemuda dan tokoh lokal setempat. Survei kondisi karang dengan menggunakan metode RRA (Rapid Reef Assesmnet) dan Metode LIT (Line Intercept Transect). Kedua metode ini menghasilkan informasi mengenai coverage terumbu karang dari lokasi survei Sesuai dengan metode yang dikeluarkan oleh BAKOSURTANAL (2005)

2. Penyuluhan dan Pelatihan Keterampilan, diberikan sebagai paket teknologi pada program yang akan dilaksanakan dalam IbM agar mitra masyarakat dapat menguasai secara teori maupun praktek teknologi yang diberikan. Penyuluhan dan pelatihan pada kegiatan :

a. Pemanfaatan terumbu karang sebagai sumberdaya perairan laut, ekosistem pesisir dan sumberdaya perikanan serta nilai valuasi karang secara ekologis.

b. Permasalahan kerusakan karang.

c. Teknik dan media transplantasi karang baik dengan desain tipe sistem rak dengan metode substrat semen (cor) dan pipa paralon.

d. Teknologi transplantasi dan pemilihan bibit karang termasuk cara seleksi untuk mendapatkan induk koloni karang yang baik untuk bibit transplantasi.

e. Teknik Reef Check karang sederhana.

3. Pendampingan dilakukan secara berkala dalam rangka pembinaan termasuk rangkaian kegiatan monitoring dan evaluasi dari awal tahapan kegiatan sampai akhir kegiatan.

4. Pembuatan papan himbauan beserta kelompoak masyarakat Desa Kombang dan masyarakat Dusun Gili Labak. Papan himbuan ini berukuran $2 \times 1 \mathrm{~m}$ yang di pasang di wilayah pantai Pulau Gili Labak. Papan himbauan ini berisi himbauan agar wisatawan menjaga terumbu karang yang ada dan tidak membuang sampah di sepanjang pantai Pulau Gili Labak.

Pelaksanaan tahapan kegiatan utama transplantasi terumbu karang adalah sebagai berikut :

1. Teknik dan media transplantasi karang dengan desain sistem rak dengan metode substrat semen (cor) dan pipa paralon Kegiatan ini dilaksanakan pada tahap awal kegiatan utama berupa penyiapan desain, teknik dan media karang dengan tahapan sebagai berikut :

- Rak yang digunakan terbuat dari bahan paralon kecil yang diisi semen dan cat agar tidak mengakibatkan pencemaran. Bentuk rangka yang digunakan berbentuk siku dengan ukuran $100 \mathrm{~cm}$ x $150 \mathrm{~cm}$.

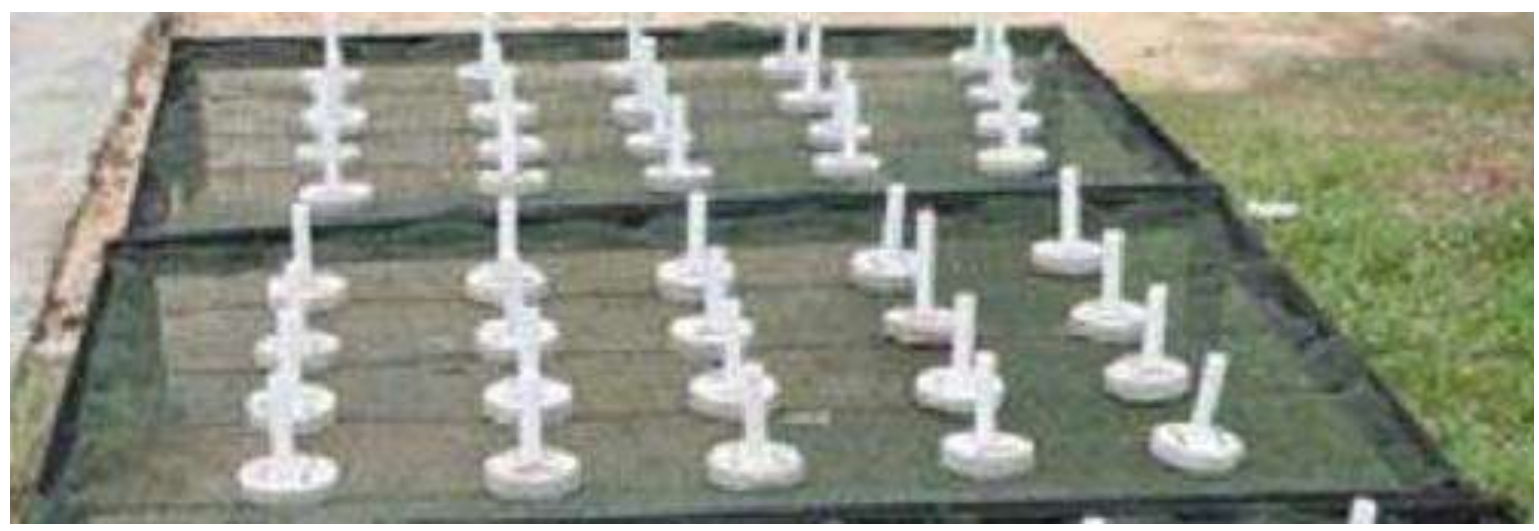

Gambar 4. Rak dari Besi Siku 

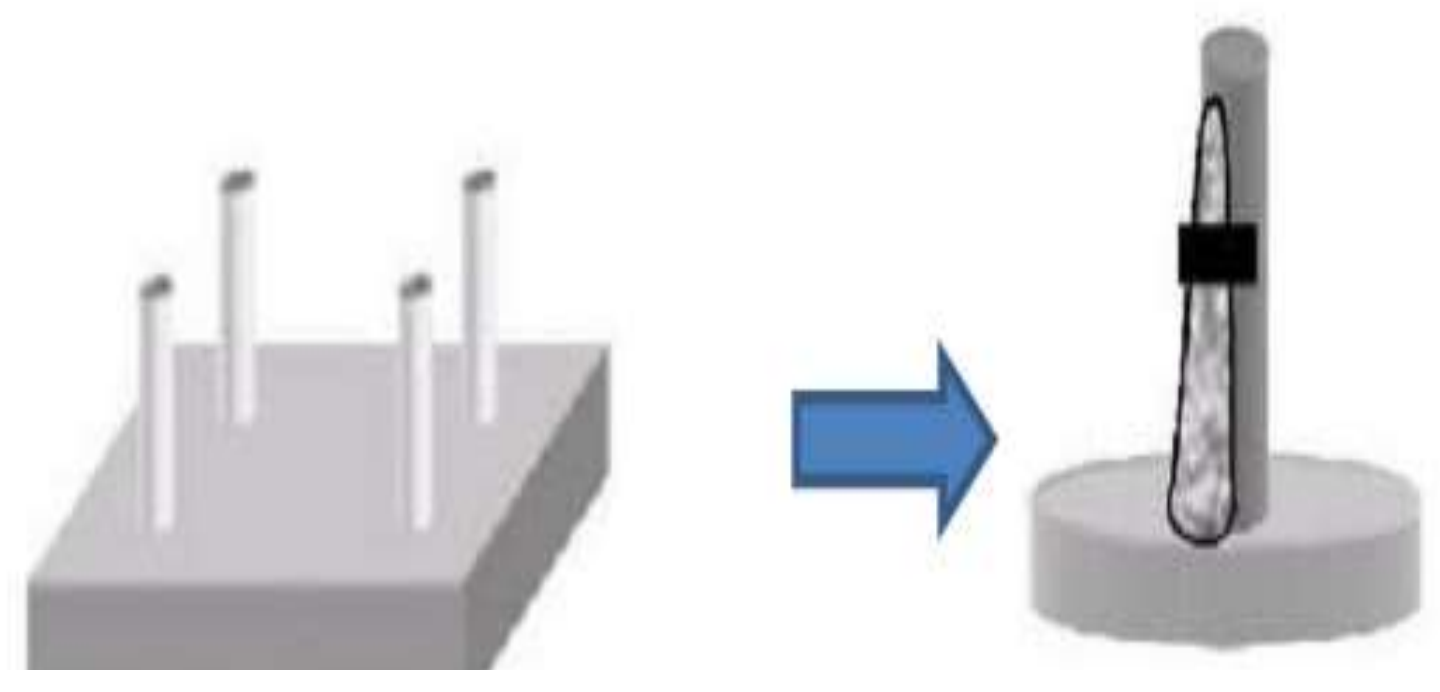

Gambar 5. Pengikatan Bibit Terumbu Karang Pada Media Semen Cor

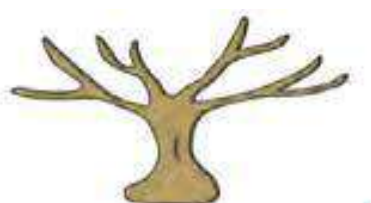

Pemilihan induk

- Sehat

- Diameter koloni lebih dari $100 \mathrm{~cm}$

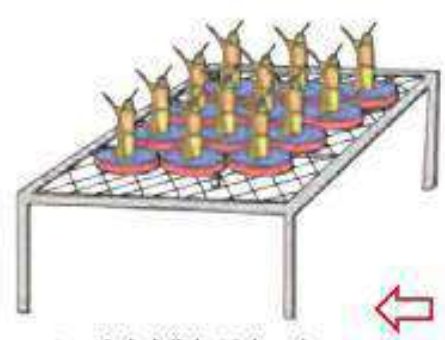

- Jumlah bibit 12 buah

- Disusun dalam 3

baris dan 4 kolom

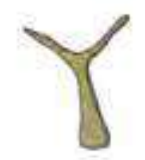

Pemotongan Anakan

- Ukuran $\pm 4 \mathrm{~cm}$

- Maksimal 1/2 bagian koloni induk

- Dilakukan di dalam air

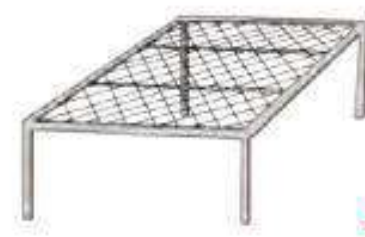

Rangka Besi

- Dicat anti karat

- Ukuran $110 \mathrm{~cm} \times 100 \mathrm{~cm} \times 50 \mathrm{~cm}$

- Alas diberi jaring PE dengan mesh size $1 \mathrm{~cm}$

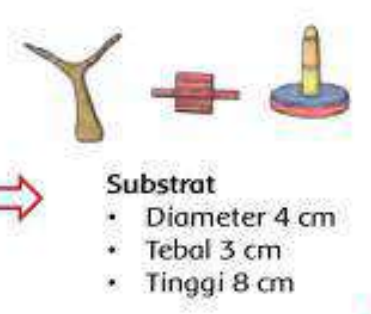

है

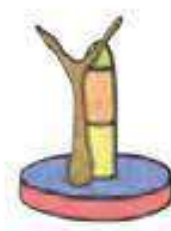

Difkat dengan tali plastik atau lem

Gambar 6. Tahapan Transplantasi Terumbu Karang Dengan Menggunakan Substrat Karang

- Diatasnya ditempat jaring mesh size

2 inci. 1 Rak pertumbuhan yang dibuat untuk sebanyak 20 unit karang. Substrat semen semen (cor) dan pipa paralon menggunakan cetakan untuk media penanaman terumbu karang. Campuran beton digunakan 1:2:3. Setelah pengecoran cetakan dilakukan perawatan cor dengan penyiraman setiap hari. Pelepasan beton dari cetakan dilakukan setelah mencapai umur cor

\section{7 hari.}

- Pengikatan substrat pada jaring berjarak kurang lebih $25 \mathrm{~cm}$. Substrat yang digunakan dalam transplantasi karang adalah substrat yang terbuat dari bahan semen, substrat ini yang nantinya digunakan sebagai tempat tumbuhnya karang.

- Kegiatan penyusunan rak dan jaring dilakukan dengan memilih media yang relatif datar, kedalamannya mendekati kedalaman pengambilan 
bibit transplantasi.

2. Aplikasi pengetahuan dan cara seleksi untuk mendapatkan induk koloni karang, yang bertujuan untuk mendapatkan bibit yang baik untuk transplantasi dilakukan dengan tahapan :

- Pemilihan koloni induk dari jenis karang bercabang khususnya famili Acropororidae (tidak menutup kemungkinan dari famili karang lainnya)

- Pengambilan bibit untuk indukan ini diambil lokasi untuk fragmen F0,

- Persiapan bibit indukan ini dilakukan dengan cara memotong beberapa karang menggunakan tang (pemotong karang) yang nantinya digunakan sebagai indukan baru.

- Ukuran koloni yang dijadikan bibit indukan tidak memperhitungkan baik besar, maupun kecilnya.

3. Monitoring dan Evaluasi Kegiatan, dilakukan pada aspek berikut :

- Peningkatan teknik dan keterampilan media transplantasi karang baik dengan sistem rak dengan metode substrat semen (cor).

- Peningkatan pengetahuan dan teknologi transplantasi dalam pemilihan bibit karang termasuk cara seleksi untuk mendapatkan induk koloni karang yang baik untuk bibit transplantasi.

- Peningkatan pengetahuan dan teknologi penanaman anakan karang.

4. Pembuatan papan himbauan beserta kelompoak masyarakat Desa Kombang dan masyarakat Dusun Gili Labak.

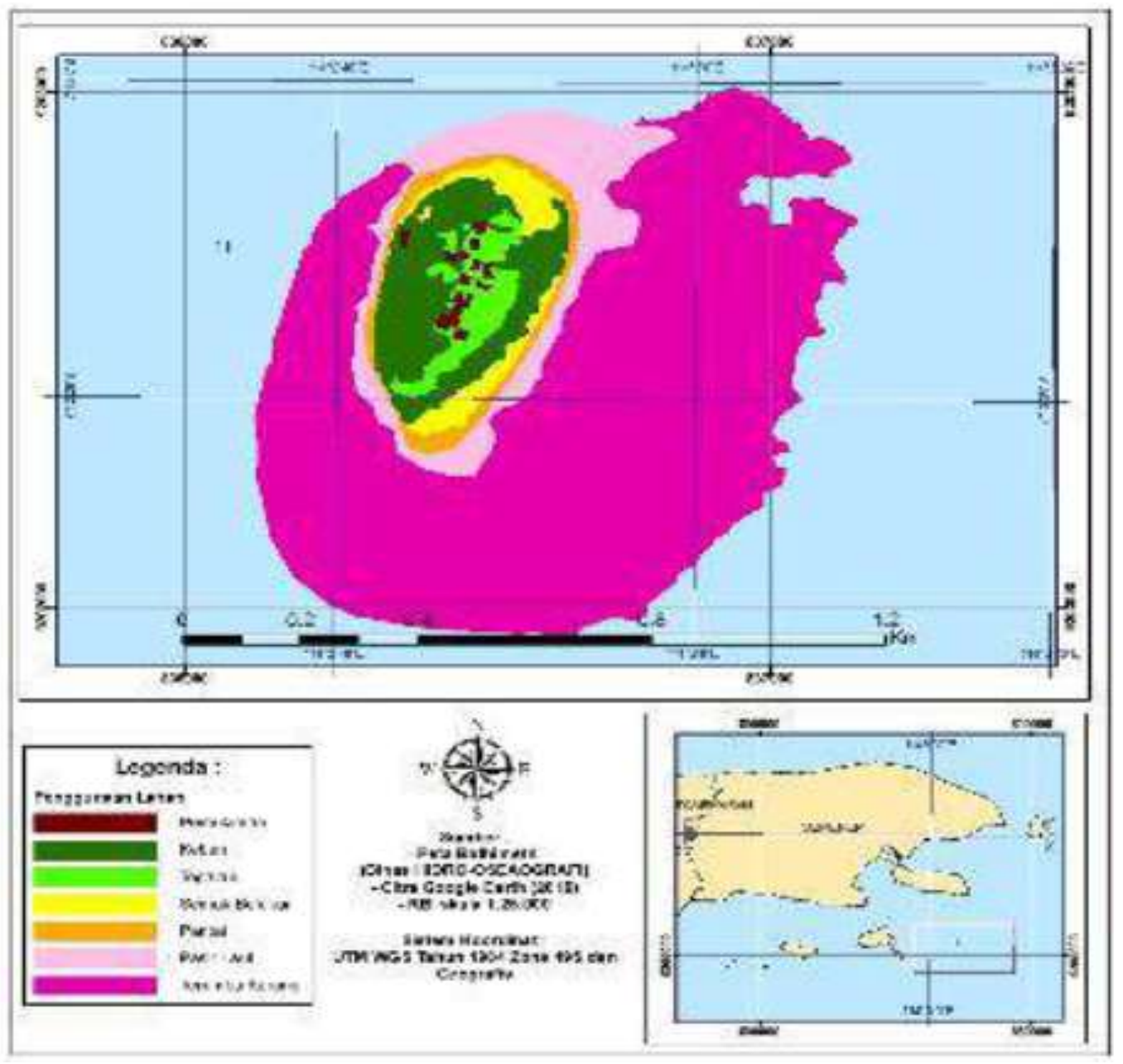

Gambar 7. Peta Tutupan Susbtrat Pulau Gili Labak 


\section{HASIL DAN PEMBAHASAN}

\section{- Kondisi Tutupan Lahan Pulau Gili Labak}

Pulau gili Labak merupakan salah satu pulau dari kurang lebih 115 pulau yang ada di Kabupaten Sumenep. Luas daratan Pulau Gili Labak sebesar 14,5 ha. Tutupan lahan di Pulau Gili Labak didominasi dengan area kebun seluas 7,07 ha $(48,6 \%)$. Kebun ini sebagian besar dengan tanaman pohon kelapa, Lamtoro dan Mimba. Ratarata kerapatan pohon mencapai 11 batang pada $100 \mathrm{~m} 2$. Tutupan lahan tegalan mencapai 2,4 ha (16,5\%) yang ditanami dengan tanaman jagung, kacang tanah atau wijen. Semak belukar mencapai luas 2,34 ha (16,2\%). Sedangkan total luas pemukiman hanya mencapai 0,58 ha (4\%). Jumlah penduduk yang ada di Pulau Gili Labak sebanyak 107 orang, yang terdiri dari 73 kepala keluarga. Luas pantai dengan pasir putih mencapai 2,14 ha $(14,7 \%)$. Peta tutupan lahan dapat dilihat pada gambar 6 dan tabel 4.

Pulau Gili Labak dikelilingi dengan pantai

Tabel 1. Luas Tutupan Lahan di Pulau Gili Labak

\begin{tabular}{|c|l|r|r|r|}
\hline No & \multicolumn{1}{|c|}{ Tutupan Lahan } & Luas $\left.\mathbf{( m}^{\mathbf{2}}\right)$ & Luas (ha) & \% \\
\hline 1. & Pemukiman & $5,808.5$ & 0.58 & 4.00 \\
\hline 2. & Kebun & $70,718.0$ & 7.07 & 48.65 \\
\hline 3. & Telagan & $24,009.6$ & 2.40 & 16.52 \\
\hline 4. & Semak Belukar & $23,405.4$ & 2.34 & 16.10 \\
\hline 5. & Pantai & $21,414.8$ & 2.14 & 14.73 \\
\hline & Luas Daratan & $\mathbf{1 4 5 , 3 5 6 . 3}$ & $\mathbf{1 4 . 5}$ & $\mathbf{1 0 0 . 0 0}$ \\
\hline 6. & Laut berpasir & $81,846.5$ & 8.18 & \\
\hline 7. & Terumbu Karang & $583,503.0$ & 58.35 & \\
\hline
\end{tabular}

Sumber : Hasil analisis peta

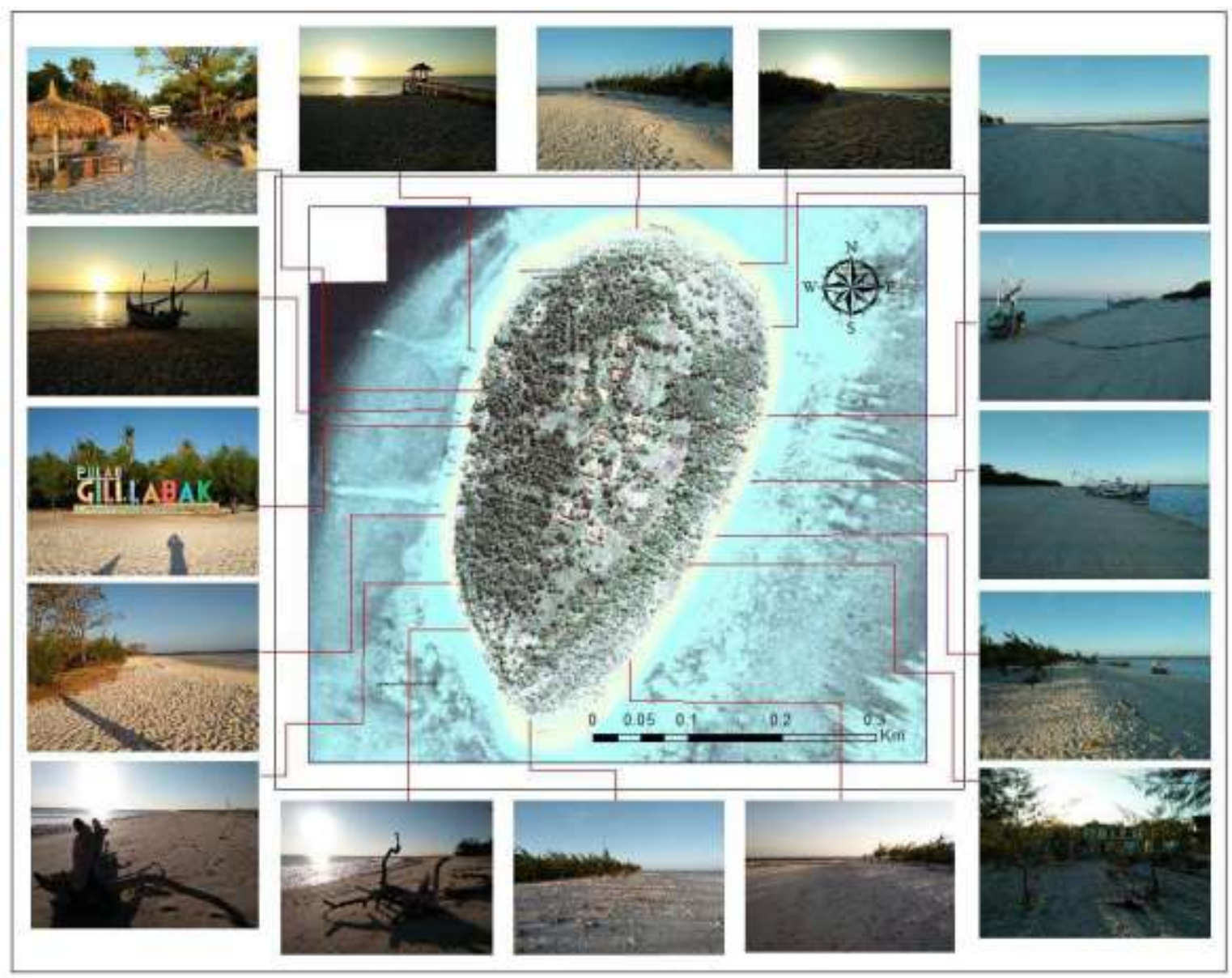

Gambar 8. Peta Kondisi Lokasi Wisata Pulau Gili Labak 
Tabel 2. Presentasi Penutupan Lifeform Terumbu Karang dengan Metode Foto Bawah Air pada Bagian Barat Pulau Gili Labak

\begin{tabular}{|c|l|r|r|r|}
\hline No & \multicolumn{1}{|c|}{ Jenis Terumbu Karang } & Luas $\left.\mathbf{( m}^{\mathbf{2}}\right)$ & Luas $\left.\mathbf{( c m}^{\mathbf{2}}\right)$ & \% \\
\hline 1. & Acropora (Branching) & 0,3864 & $3.864,8$ & 3,84 \\
\hline 2. & Echinopora (Branching) & 0,0024 & 24,1 & 0,02 \\
\hline 3. & Hydnophora (Branching) & 0,0014 & 14,2 & 0,01 \\
\hline 4. & Montipora (Branching) & 0,0605 & 604,9 & 0,60 \\
\hline 5. & Porites (Branching) & 0,0208 & 208,3 & 29,37 \\
\hline 6. & Stylophora (Branching) & 2,9593 & $29.593,3$ & 0,05 \\
\hline 7. & Caulastrea (Meandering) & 0,0046 & 45,5 & 0,75 \\
\hline 8. & Pavona (Meandering) & 0,0752 & 751,8 & 0,40 \\
\hline 9. & Psammocora (Meandering) & 0,0401 & 401,3 & 3,77 \\
\hline 10. & Favia (Massive) & 0,3797 & $3.797,6$ & 0,12 \\
\hline 11. & Oxypora (Thin Plates) & 0,0118 & 117,6 & 2,48 \\
\hline 12. & Pachyseries (Thin Plates) & 0,2499 & $2.498,5$ & 7,03 \\
\hline 13. & Porites (Thin Plates) & 0,7087 & $7.087,2$ & 0,08 \\
\hline 14. & Fungia & 0,0081 & 80,4 & 51,27 \\
\hline & Death Coral & 5,1654 & $51.654,6$ & 100,00 \\
\hline & & 10,07 & $100.744,2$ & \\
\hline
\end{tabular}

Sumber : Hasil Identifikasi Terumbu Karang Dengan Metode Transek Foto Bawah Air

pasir putih. Lokasi yang sudah banyak dikembangkan untuk wisata adalah bagian barat. Wilayah ini juga banyak untuk tambatan perahu nelayan. Fasilitas yang sudah tersedia adalah tempat berteduh /gazebo, kamar mandi dan warung penjual makanan. Selain itu juga ada fasilitas penyewaan snorkle dan pelampung untuk wisata snorkling. Sedangkan wilayah utara dan timur banyak dimanfaatkan untuk penambatan perahu tangkap nelayan Gili Labak. Untuk wilayah darat sebagian besar berupa kebun yang banyak terdapat tanaman kelapa. Buah kelapa ini juga dijadikan sebagai menu hidangan utama di warung-warung lokasi wisata. Sarana penginapan di Pulau Gili Labak dengan memanfaatkan pemukiman penduduk yang ada di Pulau ini. Sebagian besar penduduk merupakan penduduk musiman yang hanya pada saat tertentu tinggal di Gili Labak. Mata pencaharian penduduk sebagian besar sebagai nelayan. Hanya pada musim tertentu memanfaatkan lahan di sekitar pemukiman untuk bercocok tanam berupa : jagung, kacang tanah atau wijen. Sedangkan kondisi Pulau Gili Labak dapat dilihat pada gambar 7 .

\section{- Identifikasi Kondisi Terumbu Karang di Pulau Gili Labak}

Kondisi terumbu karang di Pulau Gili Labak Kabupaten Sumenep diidentifikasi dengan dengan metode Transek Foto Bawah Air seperti pada tabel 5 dan gambar 6 . Total luas foto yang diambil seluas $110.744 \mathrm{~cm} 2$. Kondisi karang hidup seluas 49.089,6 cm2 atau seluas 48,7\%. Sedangkan terumbu karang dalam kondisi mati seluas $51.654,6 \mathrm{~cm} 2$ atau seluas $51,3 \%$. Jenis karang yang dominan adalah Stylophora (Branching) dengan luas sebesar 29,27\%. Dan untuk jenis karang lain dapat dilihat pada tabel 8

\section{- Penentuan Fokus Masalah Mitra dan rekomendasi}

Mitra dalam program pengabdian ini adalah masyarakat Desa Kombang dan Masyarakat Dususn Pulau Gili Labak. Masalah- masalah ini hasil identifikasi di masyarakat dengan menggunakan kwisioner dengan metode Rapfish. Dari masalah masalah tersebut dibuat rekomendasi. Rekomendasi dibuat berdasarkan dari hasil analisis rapfish. Rekomendari inilah merupakan kegiatan yang diusulkan untuk menaikkan nilai pada masing-masing dimensi sesuai dengan interferensi yang dilakukan.

Masalah mitra yang diselesaikan dalam pengabdian ini adalah :

- Masalah ekologi, yaitu tutupan karang keras yang hidup diatasi dengan rehabilitasi terumbu karang dengan transplantasi terumbu karang yang dapat meningkatkan tutupan terumbu karang yang rusak. Penyuluhan dan papan himbuan agar tidak membuang sampah sembarangan, terutama di laut.

- Masalah potensi sumberdaya dengan adanya penangkapan yang menggunakan 
Tabel 3. Rekomendasi Kegiatan yang Disusun Berdasarkan Hasil Analisis Rapfish.

\begin{tabular}{|c|c|c|}
\hline No & Bidang & Rekomendasi \\
\hline & \multicolumn{2}{|l|}{ Dimensi Ekologi } \\
\hline 1. & Tutupan karang keras hidup (\%) & $\begin{array}{l}\text { Rehabilitasi terumbu karang dengan transplantasi terumbu karang yang } \\
\text { dapat meningkatkan tutupan karang }\end{array}$ \\
\hline \multirow[t]{2}{*}{2.} & Sampah & $\begin{array}{l}\text { Penyuluhan dan papan himbauan tidak membuang sampah di sembarangan } \\
\text { terutams di laut }\end{array}$ \\
\hline & \multicolumn{2}{|l|}{ Dimensi Potensi Sumberdaya } \\
\hline 1. & $\begin{array}{l}\text { Hasil tangkapan bapak saat ini } \\
\text { menurun jauh }\end{array}$ & Mengurangi atau tidak ada tekanan akibat penangkapan yang merusak \\
\hline \multirow[t]{2}{*}{2.} & $\begin{array}{l}\text { Alat compressor, potas dan bom } \\
\text { menurun/tidak ada }\end{array}$ & Tidak ada tekanan akibat penangkapan yang merusak \\
\hline & \multicolumn{2}{|l|}{ Bidang Ekonomi } \\
\hline 1. & $\begin{array}{l}\text { Mata pencaharian } \\
\text { penyerapan tenaga kerja }\end{array}$ & $\begin{array}{l}\text { Pelatihan untuk masyarakat, mengarahkan masyarakat untuk menjadikan } \\
\text { wisata sebagai sumber penghasilan (misalnya sebagau guide wisata atau } \\
\text { penyewaan fasilitas wisata) }\end{array}$ \\
\hline 2. & Konstribusi pariwisata (PDRD) & Mengusulkan restribusi untuk kegiatan wisata \\
\hline \multirow[t]{2}{*}{3.} & Pemanfaatan wisata & $\begin{array}{l}\text { Memberikan pelatihan kepada masyarakat } \\
\text { mengembangkan potensi Pulau. }\end{array}$ \\
\hline & \multicolumn{2}{|l|}{ Bidang social } \\
\hline 1. & Pemahaman pentingnya TK & $\begin{array}{l}\text { Memberikan penyuluhan kepada masyarakat pentingnya penjaga terumbu } \\
\text { karang dan dampaknya jika terumbu karang rusak }\end{array}$ \\
\hline 2. & Penangkapan di terumbu karang & $\begin{array}{l}\text { Pelatihan dengan menangkap ikan hias secara aman dan tanpa merusak } \\
\text { karang, mencarikan pasar untuk ikan hias hidup }\end{array}$ \\
\hline \multirow[t]{2}{*}{3.} & Merusak TK dihukum & $\begin{array}{l}\text { Sosialisasi dan penyuluhan tentang perundangan untuk menjaga lingkungan } \\
\text { (LH, SDI, SDKP) }\end{array}$ \\
\hline & \multicolumn{2}{|l|}{ Bidang Hukum dan Kelembagaan } \\
\hline 1. & $\begin{array}{l}\text { Keterlibatan nelayan dalam } \\
\text { Penyusunan kebijakan }\end{array}$ & $\begin{array}{l}\text { Melibatkan masyarakat dalam penyusunan kebijakan untuk menjadikan } \\
\text { wilayah Gili Labak sebagai tempat Ekowisata dan Sosialisasi dengan } \\
\text { intensif setiap kebijakan kepada kelompok nelayan dan masyarakat yang } \\
\text { terkait }\end{array}$ \\
\hline 2. & Peran lembaga pemerintahan & $\begin{array}{l}\text { Dinas terkait memprogramkan kegiatan khusus di Pulau Gili Labak, } \\
\text { Pendampingan kepada masyarakat di Pulau Gili Labak }\end{array}$ \\
\hline 3. & Kontribusi pemodal pribadi & Menarik investor luar untuk pengembangan Pulau Gili Labak. \\
\hline 4. & Lembaga Koperasi & $\begin{array}{l}\text { Membentuk lembaga koperasi dengan keanggotaan masyarakat dan } \\
\text { melakukan pendampingan }\end{array}$ \\
\hline 5. & Lembaga perbankan & $\begin{array}{l}\text { Menghubungkan dengan pihak perbankan untuk memberikan pinjaman } \\
\text { lunak untuk kridit nelayan (KUR) }\end{array}$ \\
\hline 6. & Lembaga Keamanan Laut & $\begin{array}{l}\text { Melakukan patroli laut secara rutin dan menindak yang melakukan } \\
\text { pelanggaran baik penangkapan yang berbahaya ataupun yang menggunakan } \\
\text { alat tangkap yang dilarang }\end{array}$ \\
\hline 7. & Kelompok Nelayan & $\begin{array}{l}\text { Membentuk kelompok nelayan di Pulau Gili labak dan melakukan } \\
\text { pendampingan kegiatan }\end{array}$ \\
\hline 8. & Peraturan Pengelolaan & $\begin{array}{l}\text { Mengusulkan peraturan daerah untuk pengelolaan ekowisata Pulau Gili } \\
\text { Labak }\end{array}$ \\
\hline
\end{tabular}

kompreseor, potas dan bom. Rekomendasi dari masalah ini adalah dengan dilakukan sosialisasi dan penyuluhan bahaya alat-alat tangkap tersebut sehingga penggunaan alat tangkap yang merusak bisa dikurangi atau tidak ada sama sekali.

- Masalah ekonomi dengan pemanfaatan potensi Gili Labak untuk wisata. Rekomendasi dengan memberikan pelatihan kepada masyarakat Gili labak untuk mengembangkan potensi Pulau.

- Masalah sosial kurangnya pemahaman masyarakat tentang manfaat dan pentingnya terumbu karang. Rekomendasi dengan memberikan penyuluhan kepada masyarakat pentingnya penjaga terumbu karang dan dampaknya jika terumbu karang rusak

- Kelompok nelayan, rekomendasi dengan membentuk kelompok nelayan di

- Pulau Gili labak dan melakukan pendampingan kegiatan 

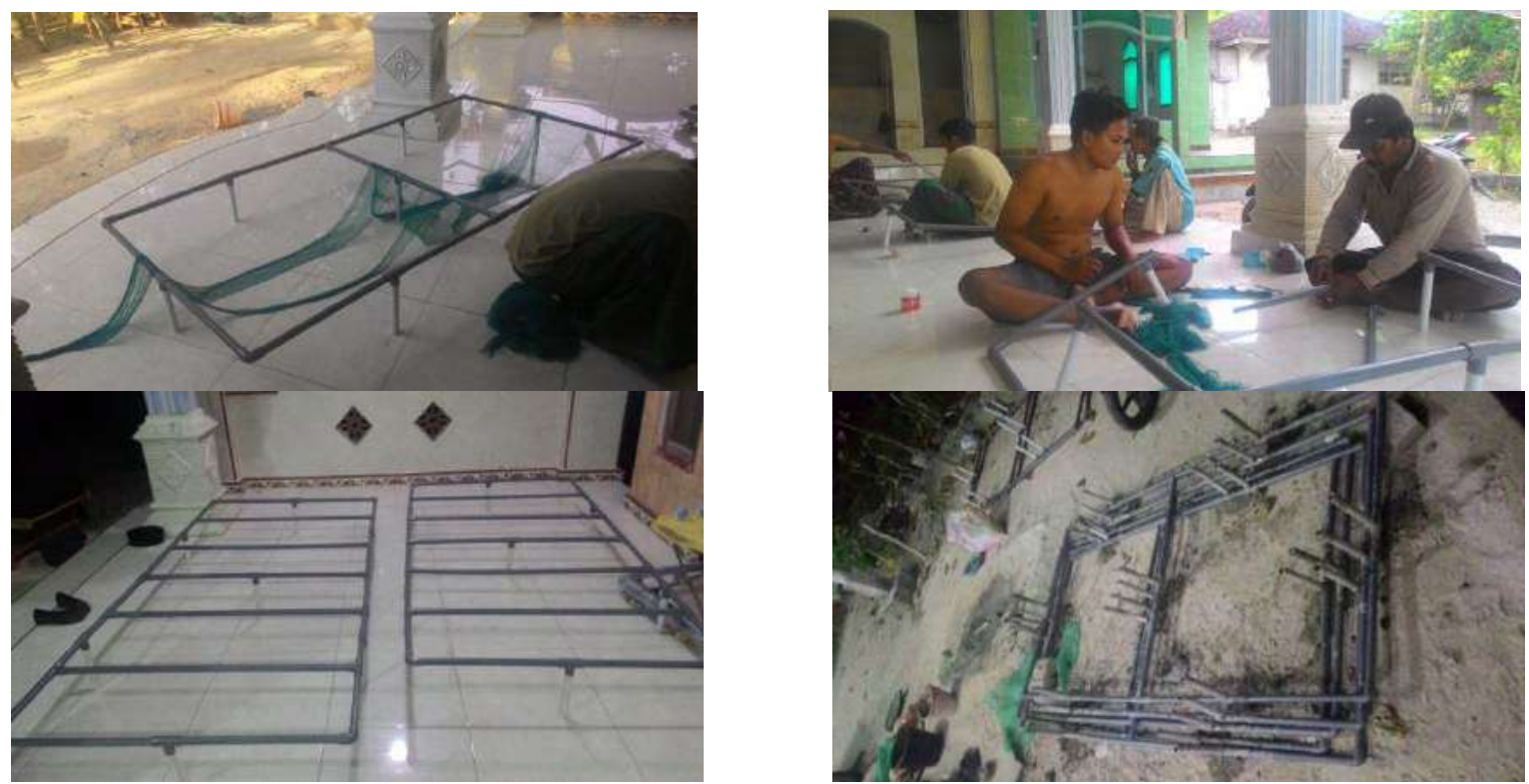

Gambar 9. Pembuatan Rak dan Media Untuk Transplantasi Terumbu Karang.

\section{- Pengabdian Transplantasi Karang di Desa Pulau Gili Labak}

Tahapan yang dilakukan dalam pengabdian ini adalah : 1) Persipan untuk transplantasi terumbu karang; 2) penyuluhan dan pelatihan; 3 ) evaluasi dan pendampingan; 4) pembuatan papan himbauan. Tahapan survey lokasi dan terumbu karang dan identifikasi masalah sudah dilakukan dengan metode Rapfis menggunakan kwisioner.

1. Persipan untuk transplantasi terumbu karang

Tahapan persiapan untuk tranplantasi terumbu karang adalah, antara lain :

- Pembuatan rak untuk tranplantasi karang. Pembuatan rak ini dilakukan dengan melibatkan masyarakat desa Kombang. Harapannya selain mereka mendapatkan pengetahuan untuk mempersiapkan transpalntasi karang, akan timbul kesadaran untuk menjaga dan mebudidayaka terumbu karang kedepannya.

- Pembuatan Poster, Bener dan stiker. Dalam mendukung kegiatan pengabdian ini dibuat beberapa poster dan bener. yaitu :

a. Poster potensi wisata Pulau Gili Labak, berisikan potensi dan kondisi pulau gili Labak untuk pengembangan wisata.

b. Poster tentang manfaat terumbu karang, harapannya akan lebih mempermudah dan menerik bagi mesyarakat untuk memahami manfaat erumbu karang.

c. Poster tentang metode transplantasi terumbu karang, harapannya akan lebih mempermudah dan menerik bagi mesyarakat untuk memahami manfaat terumbu karang.

d. Bener : "Buang sampah pada tempatnya, mengapa tidak?". Dampak negatif sampah : pencemaran lingkungan, timbulnya penyakit, mengganggu keindahan. Bener ini di pasang di lokasi wisata Gili Labak, harapannya menimbulkan kesadaran masyarakat dan pengunjung

e. Bener : "Jaga dan Cintai Terumbu Karang - Karena Mereka Juga Ingin Hidup". Bener ini di pasang di lokasi wisata Gili Labak, harapannya menimbulkan kesadaran masyarakat dan pengunjung

f. Bener untuk pelatihan

g. Stiker, kebutuhannya untuk 
ditempel oleh para peserta pelatihan sehingga sebagai sarana untuk sosialisasi menjaga terumbu karang dan kebersihan.

- Pembuatan video yang upload di media youtube sebagai sarana publikasi dan sosialisasi ke pihak luar. Video youtube tentang

a. Tentang terumbu karang di gili Labak , alamat web https://www.youtube.com/watch $? \mathrm{v}=5 \times \mathrm{x} I \mathrm{ke} \mathrm{RC} 3 \mathrm{~s} \& \mathrm{t}=4 \mathrm{~s}$

b. Tentang transplantasi karang, alamat web https://www.youtube.com/watch ? $\mathrm{v}=\mathrm{bHz} 1 \mathrm{KVZatkI} \& \mathrm{t}=2 \mathrm{~s}$

2. Pelaksanaan Pelatihan dan Penyuluhan Transplantasi Terumbu Karang di Desa Kombang Pulau Poteran dan Dusun Gili Labak

Pelaksanaan Pelatihan dilaksanakan di dua tempat, yaitu : mitra pertama kelompok masyarakat Desa Kombang Pulau Poteran, yang pelaksanaan pelatihan pada hari saptu (5 Agustus 2017) jam $10.00 \mathrm{WIB}$, jumlah peserta sebanyak 20 orang dan yang kedua kelompok masyarakat Dusun Gili Labak di Pulau Gili Labak pada hari Saptu, Jam 19.00 WIB malam dengan jumlah peserta 17 orang. Tujuan pelatihan

ini adalah :

- Menumbuhkan kesadaran di kalangan Desa Kombang dan Dusun Gili Labak tentang manfaat terumbu karang dan hal-hal yang dapat merusak terumbu karang, serta mengetahui teknik rehabilitasi karang dengan melakukan transplantasi terumbu karang.

- Menumbuhkan kesadaran masyarakat Desa Kombang dan Dusun Gili Labak tidak melakukan penangkapan yang dapat merusak ekosistem terumbu karang (menggunakan bom atau potas). Serta menjaga tetap menjaga ekosostem terumbu karang
- Masyarakat mampu memanfaatkan peluang potensi alam untuk ekowisata sehingga masyarakat mendapatkan keuntungan ekonomi.

- Menumbuhkan kesadaran masyarakat Desa Kombang dan Dusun Gili Labak untuk mencintai terumbu karang dan menjaga kebersihan dengan tidak membuang sampah sembarangan terutama ke laut.

- Mulai membentuk kelompok masyarakat sadar lingkungan.

Materi Pelatihan transplantasi terumbu karang :

- Materi tentang manfaat terumbu, yang berisi tentang pemahaman Terumbu Karang adalah sekumpulan hewan karang yang bersimbiosis dengan sejenis tumbuhan alga yang disebut zooxanhellae. Pertumbuhan karang : Karang cabang (Acropora) $\rightarrow 10-15 \mathrm{~cm}$ per tahun, karang masif $\rightarrow 0,8-1,0 \mathrm{~cm}$ per tahun. Manfaat terumbu karang : (1) Tempat hidup ikan seperti ikan kerapu, ikan baronang, ikan ekor kuning) $\rightarrow$ sebagai tempat makan, pemijahan, pembesaran, dan asuhan; (2) Pariwisata bahari melihat keindahan bentuk dan warnanya; (3) Penelitian dan pemanfaatan biota perairan; (4) Penahan abrasi pantai yang disebabkan gelombang dan ombak laut, serta sebagai sumber keanekaragaman hayati. Macam dan bentuk terumbu karang : bentuk meja, otak, bercabang, spiral dan tonggak. Aktivitas yang nerusak terumbu karang: Membuang sampah ke laut dan pantai yang dapat mencemari air laut, Membawa pulang ataupun menyentuh terumbu karang saat menyelam, Membuang jangkar pada pesisir pantai secara tidak sengaja akan merusak terumbu karang yang berada di bawahnya, Terdapatnya predator terumbu karang, seperti sejenis siput drupella, Penambangan karang, pembangunan 
pemukiman, reklamasi pantai, polusi, penangkapan ikan dengan cara yang salah, seperti pemakaian bom ikan

- Materi tentang potensi wisata Pulau Gili Labak. Luas Pulau Gili Labak sebesar 14,5 ha. Penggunaan lahan di Pulau Gili Labak terdiri dari Kebun 7,07 ha $(48,6 \%)$, tegalan 2,4 ha $(16,5 \%)$, semak belukar 2,34 ha $(16,2 \%)$, pemukiman 0,58 ha $(4 \%)$. Jumlah penduduk 107 orang, terdiri dari 73 KK. Terdapat di Kecamatan Talango. Ciri khas dan keunikan ekosistemnya adalah pantai pasir putih (luas 2,14 ha) dan terumbu karang yang beraneka warna dengan luas 66 ha, keanekaragaman ikan hias dan satwa laut lainnya, cocok untuk olahraga selam. karang hidup seluas $48,7 \%$. Jenis karang yang dominan adalah Stylophora (Branching). suhu air 30-31.2 $0 \mathrm{C}$, pH 7-8, Salinitas berkisar 25-32 $0 / 00$, oksigen terlarut $5,98-8,59$ $\mathrm{mg} / \mathrm{L}$, kecerahan $100 \%$.

- Materi tentang teknik transplantasi terumbu karang, yaitu : (1) tahap awal Pemilihan induk ( Sehat, diameter koloni karang mencapai lebih dari $100 \mathrm{~cm}$ ); (2) Pemotongan anakan (ukuran $4 \mathrm{~cm}$, maksimal $1 / 2$ bagian koloni induk, pemotongan dalam air); (3) pembuatan Substrat (diameter $10 \mathrm{~mm}$, tebal $3 \mathrm{~cm}$, tinggi $8 \mathrm{~cm}$ ); (4) Diikat dengan tali plastik atau dengan semen perekat; (5) Pemasangan pada rangka dari paralon/besi (ukuran 110x110 cm), diberi jaring PE; (6) Penanaman transplantasi karang.

\section{- Output Kegiatan}

Kegiatan kegiatan IbM ini adalah :

1. Seminar Nasional Kelautan dan Perikanan III UTM, pada tanggal 6 September 2017.

2. Publikasi ke media Youtube Tentang

3. Draf Buku Ajar

\section{KESIMPULAN}

Dimensi ekologi dalam kategori cukup berkelanjutan (62,3), dimensi sumberdaya dalam kategori cukup berkelanjutan $(63,07)$, Dimensi ekonomi dalam kategori tidak berkelanjutan $(10,15)$, Dimensi sosial dalam kategori tidak berkelanjutan $(17,8)$, Dimensi Hukum dan kelembagaan dalam kategori tidak berkelanjutan (5,36), Hasil analisis multidimensi pada kategori kurang berkelanjutan (34,24). Setelah dilakukan interferensi meningkat menjadi cukup berlanjut (nilai 74,99). Interferensi ini yang dijabarkan dalam rekomendasi.

Masalah mitra yang diselesaikan dalam pengabdian ini adalah : Masalah ekologi, yaitu tutupan karang keras yang hidup diatasi dengan rehabilitasi terumbu karang dengan transplantasi terumbu karang. Penyuluhan dan papan himbuan agar tidak membuang sampah sembarangan, terutama di laut. Masalah potensi sumberdaya dengan adanya penangkapan yang menggunakan kompreseor, potas dan bom. Masalah ekonomi dengan pemanfaatan potensi Gili Labak untuk wisata. Masalah sosial kurangnya pemahaman masyarakat tentang manfaat dan pentingnya terumbu karang. Kelompok nelayan, rekomendasi dengan membentuk kelompok nelayan di Pulau Gili labak dan melakukan pendampingan kegiatan

Tahapan pengabdian Transplantasi terumbu karang adalah : 1) Persiapan (Pembuatan rak untuk tranplantasi karang, Pembuatan Poster, Bener dan stiker, Pembuatan video yang di upload di media youtube; 2) penyuluhan dan pelatihan (materi Materi tentang manfaat terumbu, Materi tentang potensi wisata Pulau Gili Labak, Materi tentang teknik transplantasi terumbu karang) 3) evaluasi dan pendampingan; 4) pembuatan papan himbauan

Evaluasi Pelatihan Transplantasi Terumbu Karang : sebelum pelatihan menunjukkan $92 \%$ peserta pelatihan tidak tahu manfaat pentingnya terumbu karang dan $8 \%$ kurang tahu, dengan pelatihan $92 \%$ menjadi tahu manfaat pentingnya terumbu karang dan $4 \%$ tahu, dengan pelatihan $84 \%$ peserta menganggap perlu sekali terumbu karang dijaga dan $16 \%$ menganggap perlu, dengan pelatihan $88 \%$ peserta menjadi tahu sekali jika terumbu karang bisa di 
tanam/budidayakan dan $8 \%$ tahu, dengan pelatihan $88 \%$ berpendapat pelatihan ini bermanfaat sekali untuk memberikan pemahaman terhadap perlunya menjaga terumbu karang dan $12 \%$ menjawab bermanfaat, $84 \%$ peserta pelatihan berpendapat pelatihan ini bermanfaat sekali untuk memberikan pemahaman cara menanam terumbu karang dan $16 \%$ berpendapat bermanfaat; $84 \%$ peserta pelatihan berpendapat sangat bersedia di kemudian hari menjaga terumbu karang di Gili Labak dan $16 \%$ bersedia

Hasil Valuasi ekonomi Pulau Gili Labak sebesar Rp. 158,407,021,311,-. Nilai manfaat langsung sebanyak Rp. 121.832.209.503,(77\%), Nilai manfaat tidak langsung sebesar Rp. $12,938,199,340,-(8 \%)$, nilai manfaat pilihan sebesar Rp. 8,453,391,518,- (5\%), nilai pewaris sebesar Rp. 12,183,220,950 (8\%), dan nilai keberadaan sebesar Rp. 3,000,000,000 (2\%).Perlu dilakukan monitoring kedepan untuk mengetahui perkembangan hasil transplantasi terumbu karang.

\section{DAFTAR PUSTAKA}

Anonimous, 2005. Pedoman Survei dan Pemetaan Terumbu Karang. Bakosurtanal

Cesar, H. 1996. Economic Analysis of Indonesian Coral Reefs. The World Bank

Hasmin, 2006. Penilaian Ekonomi Ekosistem Terumbu Karang di Perairan Pulau Kapoposang, Sarappo Keke dan Saugi Kabupaten Pangkep. Tesis Pascasarjana UNHAS, Makassar.

Harahab, N., 2010. Penilaian Ekonomi Ekosoistem Hutan Mangrove dan aplikasinya dalam Perencanaan Wilayah Pesisir. Yogyakarta : Graha Ilmu.

Fauzi, Akhmad. 2002. Valuasi ekonomi sumberdaya pesisir dan lautan. Makalah pada Pelatihan Pengelolaan Sumberdaya Pesisir dan Lautan. Semarang: Universitas Diponegoro.

Muhsoni, F.F.M. 2013. Pemetaan Kondisi Terumbu Karang di Pulau
Mandangin.Lembaga Penelitian dan Pengabdian Kepada Masysrakat Universitas Trunojoyo Madura

Muhsoni, F.F. Syarif M.S.,Effendi M. 2011. Inventarisasi Data Potensi Sumberdaya Wilayah Pesisir Kabupaten Sumenep. Jurnal Kelautan, 4(1) :96-101.

Muhsoni. 2016. Pemodelan Daya Dukung Pemanfaatan Pulau Sapudi Dengan Menggunakan Sistem Informasi Geografis. Jurnal Kelautan, 9(1) : 73-84.

Muhsoni. 2015a. Pemanfaatan Citra Satelit LDCM untuk Pemetaan Kerapatan Tajuk mangrove dan Terumbu Karang. Prosiding Semnas Perikanan dan Kelautan FPIK UB. ISBN : 978-602-72784-0-0.

Muhsoni. 2015b. Pemetaan Terumbu karang Pulau Gili Labak dengan Metode Transek Foto Bawah Air dan Citra Satelit LDCM untuk Arahan Pemanfaatan Ekowisata. Prosiding Semnas Kelautan Universitas Trunojoyo Madura. ISBN : 978-602-799889-6

Keputusan Menteri Kelautan dan Perikanan Nomor : KEP.38/MEN/2004 Tentang Pedoman Umum Pengelolaan Terumbu Karang

Sulistianto, E. 2010. Penilaian Ekonomi Ekosistem Terumbu Karang di Perairan Bontang Kota Bontang. Jurnel EPP.7 (1) : 20-24

Subekti, J., Suradi W. S. , Imam T. .2013. Valuasi Pemanfaatan Sumberdaya Perikanan Ekosistem Terumbu Karang Pada Taman Nasional Kepulauan Seribu, Jakarta. Jurnal of Management of Aquatic Resources. 2 (3): 104-108

White, A.T. dan A. Cruz-Trinidad, 1998. The Values of Philippine Coastal Resources: Why Protection and Management Are Critical (Cebu City, Philippines: Coastal Resource Management Project). 